\title{
Epinephrine in the tumescent technique for hypospadia surgery
}

\author{
Theddeus O.H. Prasetyono, ${ }^{1,2}$ Nandita M. Putri ${ }^{1}$ \\ ${ }^{1}$ Division of Plastic Surgery, Department of Surgery, Cipto Mangukusumo Hospital/Universitas Indonesia, Jakarta, Indonesia \\ ${ }^{2}$ Indonesian Clinical Training and Education Center (ICTEC), Cipto Mangukusumo Hospital/ Universitas Indonesia, Jakarta, \\ Indonesia
}

\begin{abstract}
Abstrak
Penggunaan teknik tumescent yang mengandung epinefrin pada pembedahan penis belum pernah dilaporkan sebelumnya. Dua pasien dengan hipospadia menjalani operasi rekonstruksi menggunakan teknik tumescent menggunakan larutan "One-per-Mil” yang mengandung epinefrin. Hasil yang didapatkan adalah lapangan operasi yang bersih, hampir tanpa pendarahan bermakna saat pemotongan dan tanpa komplikasi pada penis setelah suntikan epinefrin dengan sedikit edema. Larutan tumescent "One-per-Mil” bertindak sebagai hydro-dissector yang menghasilkan lapangan operasi relatif avaskular yang memudahkan pengenalan jaringan serta mempercepat diseksi pada operasi hipospadia. Untuk sementara, epinefrin berdosis rendah disimpulkan aman untuk disuntikkan pada penis dalam praktek klinis di masa depan. (Med $\boldsymbol{J}$ Indones. 2012;21:175-8)
\end{abstract}

\begin{abstract}
The use of tumescent technique, which contains epinephrine, in penile surgery has not been reported previously. Two patients with hypospadias had reconstructive operation using tumescent technique with a "One-per-Mil" tumescent solution containing epinephrine intra-operatively. The results was a clear operation field, almost bloodless during dissection, and no complication on the penis after epinephrine injection with minimal edema. Apparently, the "One-perMil" tumescent solution acts as a natural hydro-dissector creating avascular anatomic tissue planes for easier and more rapid dissection in surgery for hypospadias. We suggest that epinephrine is safe to be injected in penis as a future area of clinical practice. (Med J Indones. 2012;21:175-8)
\end{abstract}

Keywords: Epinephrine, hypospadia, tumescent technique

Hypospadias is the most common congenital anomaly of the penis, affecting $0.4-8.2$ of 1000 live male babies. ${ }^{1}$ The urethral meatus ectopically located proximal to the normal place on the ventral side of the penis is the characteristic of this congenital anomaly. Different anatomic presentations can be observed depending on the position of the urethral meatus. The penile surgery itself is a complicated and delicate surgery, because it involves one of the most vascularized organ, and the artery is an end-arterial type. Hypospadias surgery is usually performed in children who had smaller vessels size, thus the reconstruction surgery is more challenging for the surgeon.

In plastic surgery, the indications for tumescent itself have expanded broadly.Initially, the tumescent was only used for assistance with suction-assisted lipectomy, but now it is used in various surgeries such as breast, facial, body contouring surgery, and also hand surgery. ${ }^{2}$ The advantages of tumescent technique have been well published within the literature. They include shorter surgical times, less postoperative edema, reduced risk of hematomas, improved postoperative pain control, and avoidance of general anesthetic when paired with conscious sedation techniques. In addition, when infiltrated at the appropriate depth, the tumescent solution acts as a natural hydro-dissector, creating avascular anatomic tissue planes for easier and more rapid dissection. ${ }^{2}$
The use of epinephrine in tumescent solutions has long been described with many different kinds of concentration depending on the preference of each surgeon. To date, various concentrations of epinephrine, mostly from $1: 100,000$ to $1: 400,000$ have been used in the clinical setting, while in experimental study, the lowest concentration of tumescent solution was 1:800,000. ${ }^{3}$ The study on a skin flap survival in rats after injection of lidocaine and epinephrine as tumescent technique revealed that lidocaine with epinephrine in concentrations of 1:400,000 and 1:800,000 was found safe on skin flap survival for tumescent technique in rats. ${ }^{3}$

The safety of using epinephrine in end arterial structures was often questioned. Many textbooks and references note that digital ischemia can be a problem after the use of epinephrine, especially in concentrated forms. But, a retrospective cohort study on cases reported to 6 poison centers during 6 years, using a search of the Texas Poison Center Network database concluded that ischemia after digital epinephrine auto-injection is rare. ${ }^{4}$ Hence, there is a growing body of evidences that suggests that the use of epinephrine in the fingers at low concentrations $(1: 100,000$ to $1: 200,000)$ typically found in local anesthetic mixtures for the purpose of digital nerve blocks is safe and without adverse effects. ${ }^{5}$ This evidence comes from small clinical trials, large observational registries, and studies of digital blood flow. There have been no reports of digital gangrene 
after the use of epinephrine for digital blocks since the introduction of a commercially prepared mixture of lidocaine and epinephrine. An extensive review of the literature from 1880 to 2005 identified 48 cases of digital gangrene after local anesthesia of the finger. Of these, only 21 cases involved epinephrine that was injected in combination with procaine, not lidocaine. Subsequent analysis demonstrated that, at the time, enforcement of medication expiration dates was poor and that over time procaine degraded into para-aminobenzoic acid, contributing to a highly acidic environment that was responsible for tissue loss both in fingers and elsewhere in the body. ${ }^{5}$

Epinephrine is a sympathomimetic amine with both $\alpha$ - and $\beta$-adrenergic receptor agonist effects. ${ }^{6}$ Skin, mucosa, and kidney arterioles display vasoconstriction due to $\alpha$-receptor predominant stimulation. Low concentrations of epinephrine result in preferential $\beta-2$ receptor stimulation resulting in vasodilatation in bronchiolar smooth muscle while higher levels stimulate $\alpha$-receptor-mediated vasoconstriction in vascular smooth muscle. Epinephrine therefore reduces the absorption of local anesthetic agents in the circulation, resulting in decreased systemic effects, increased duration of action and decreased surgical blood loss. ${ }^{6}$ The combination of epinephrine with a local anesthetic such as lidocaine results in a predominant vasoconstrictive effect, producing a significant decrease in perfusion. ${ }^{6}$ This combination as well as lidocaine alone are frequently used in reconstructive procedures such as skin tumor excision and local flap closure in addition to cosmetic surgical procedures. ${ }^{6}$

This prompted our study, the aim of which was to determine the effect of epinephrine in conjunction with lidocaine by tumescent technique in penile surgery, which is an end arterial organ, and in relevant to plastic surgery is the reconstruction of hypospadias. However, the initial report of these 2 cases will be only a preliminary to catch the timing of publishing new idea. A subsequently larger series will follow this report.

\section{CASE PRESENTATION}

\section{Case 1}

The first patient was a 3 year-old boy admitted for the first stage reconstruction of penile type hypospadias. We used a no tourniquet method for this operation; instead the tumescent technique was used to facilitate the chordae release and the creation of the intra-glans neourethra through a tunneling technique.The "One-perMil" tumescent solution made by adding epinephrine $(1: 1000,000$ concentration) and lidocaine $(20 \mathrm{mg})$ in saline solution of a total $50 \mathrm{~mL}$ solution was injected in the penile skin. The surgery was done properly in a clear operating field, which was relatively bloodless. No adverse event detected during and after surgery related to the use of epinephrine injection. The patient healed uneventful, although we could not check the patency of the distal neourethra since we need to wait for the next stage of surgery to be able to examine it under general anesthesia.

\section{Case 2}

The second patient is an 8 year-old boy with a history of multiple congenital anomalies. He was born with anal atresia and perineal type of hypospadias along with scrotal bifid. He had undergone several surgeries including colostomy, anal reconstruction, stoma closure, twice efforts on chordae release (see figure 1 for the clinical image before the urethroplasty).

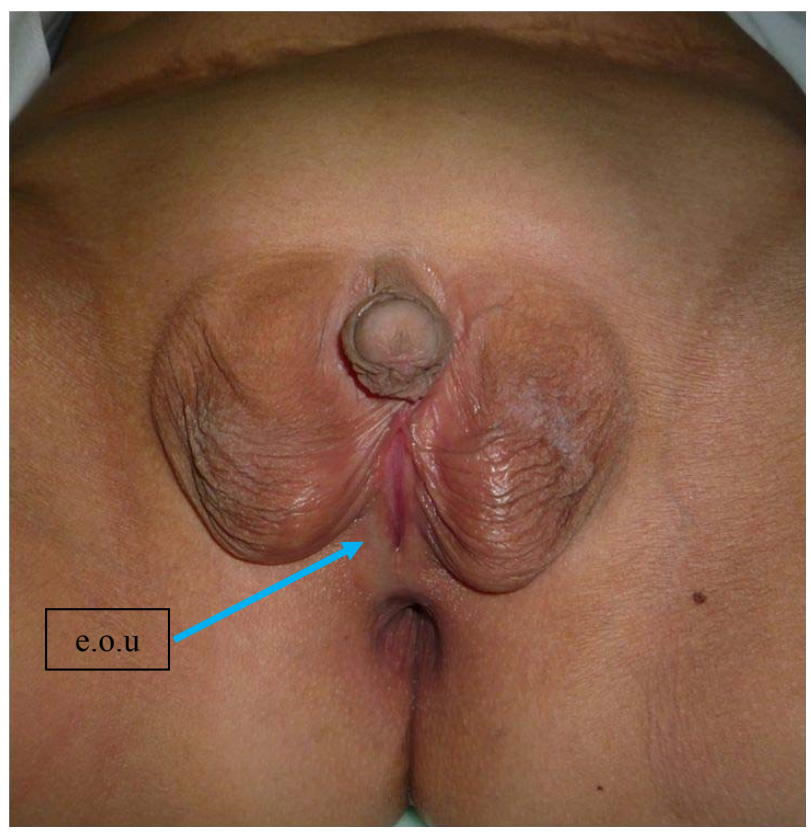

Figure 1. Pre-operative image. The arrow shows the external orificium of urethra. The picture shows also the $a b-$ dominal scar on top of the image

The last operation for hypospadias reconstruction he had undergone was urethroplasty after chordae release done by other doctor (pediatric surgeon). We did the secondary chordae release and creating the intra-glans neourethra, more or less a year before the last surgery (see figure 2 for the patency of the neourethra). That first surgery we did was without epinephrine and hydro-dissection. The second surgery was the long way urethroplasty with the use of "One-per-Mil" tumescent solution. Figure 2, 3, and 4 show the tumescent injection with minimal bleeding during surgery. Inzet on the left side of figure 4 is a comparator of bloody operating field 


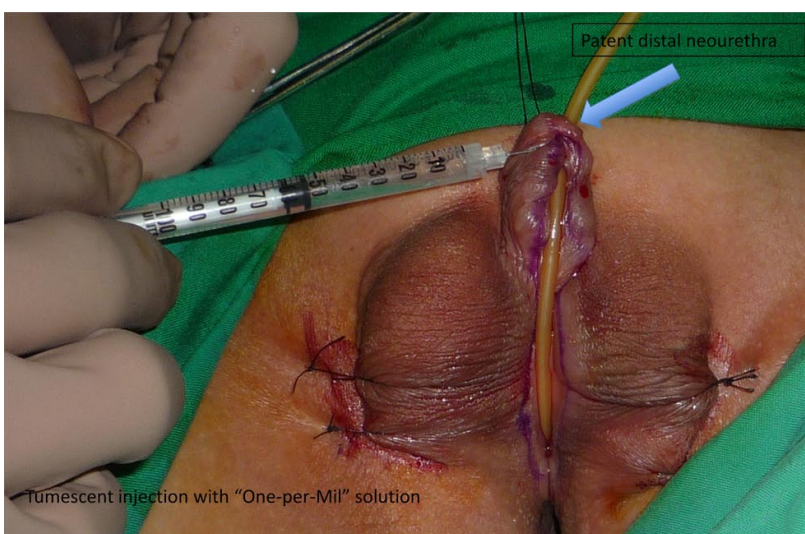

Figure 2. Injection of "One-per-Mil" tumescent solution. It is shown also the previously made distal neourethra inside the glans is patent

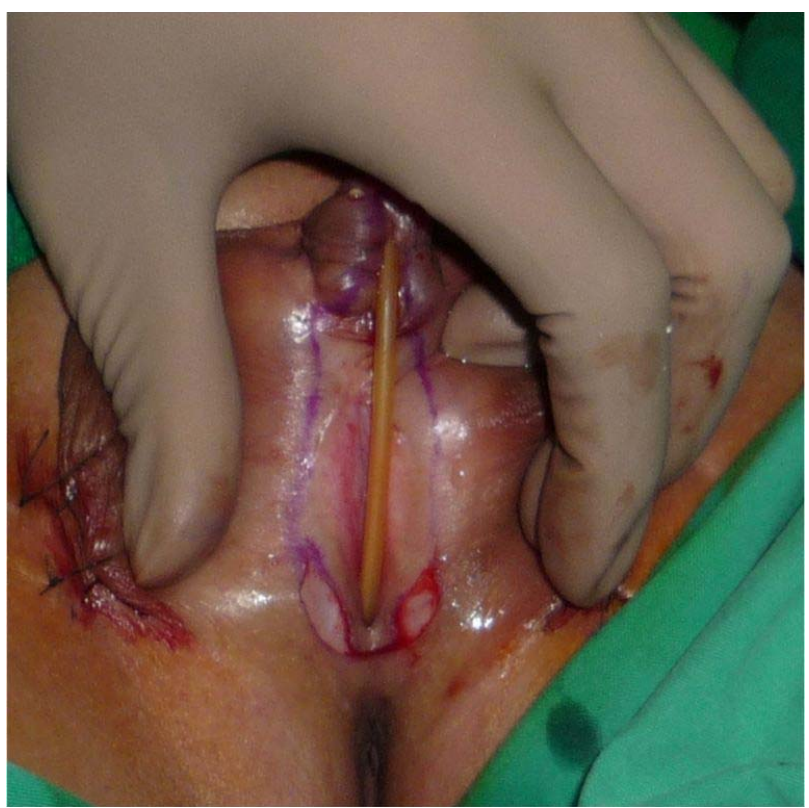

Figure 3. Incisional wound with minimal bleeding

when the patient underwent secondary chordae release and intra-glans urethral reconstruction. The surgery was considered a success after a 6 month follow-up, leaving only a small urethrocutaneous fistula on the distal penile body.The author plans to repair the fistula and reconstruct the scrotal bifid after 6 months. The patient urinates by standing, leaving only dripping of the urine through a small single fistula (Inzet in figure 4 shows the penis 6 months after surgery). A movie clip is attached to this article showing the intraoperative bloodless operating field.

\section{DISCUSSION}

Tumescence is the injection of local anesthetic and crystalloid into the subcutaneous tissue to establish a bloodless plane for surgical dissection. ${ }^{7}$ The classic tumescent anesthesia described by Klein, with a

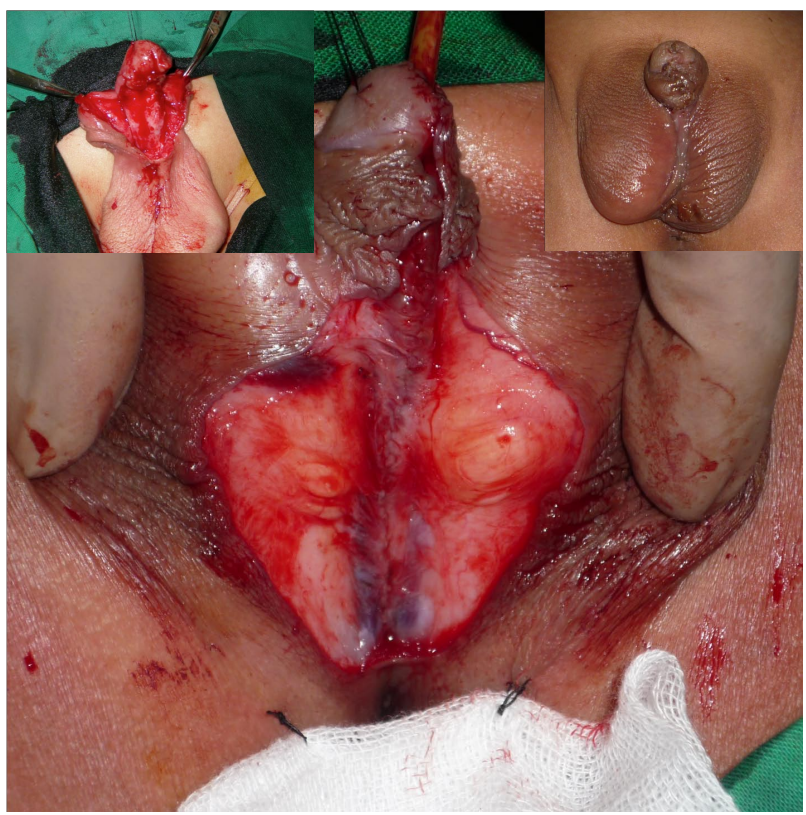

Figure 4. The tumescent injection gave a relatively clear operating field without excessive bleeding as it uses to be in penile surgery. Inzet on the left side shows bloody operating field without epinephrine injection. The final appearance on 6 months after surgery is on the right inzet.

standard formula of $0.05 \%$ lignocaine and 1:1,000,000 epinephrine plus sodium bicarbonate $(8.4 \%)$ in 1 L of saline $(0.9 \%)$ works well for liposuction procedures. ${ }^{8}$ But nowadays, there have been many modifications made by surgeons for this solutions. The basic principle common to all techniques is the delivery of a large amount of fluid with a local anesthetic and a vasoconstrictor. This results in swelling, i.e., tumescence, of the operative field. ${ }^{9}$ This report uses a tumescent solution which was prepared by adding epinephrine (1:1,000,000 concentration) and lidocaine $(20 \mathrm{mg})$ in saline solution of a total $50 \mathrm{~mL}$ solution creating a"One-per-Mil" tumescent solution.This tumescent solution was developed originally by Prasetyono in his unpublished paper titled Tourniquet-free hand surgery by "One-per-Mil" tumescent technique. In our hospital, the tourniquetfree hand surgery by "One-per-Mil" tumescent technique has been used since 2010 and the safety of using epinephrine in hand surgery is confirmed. But the use of this technique, which contains epinephrine in penile surgery has not been reported yet.

The standard operational procedure in hypospadias surgery in our hospital is that the patient is under general anesthesia and either caudal or dorsal penile block is additionally given. Tourniquet is not a common technique in hypospadias surgery; thus surgeon used to work in a relatively bloody operating field. The battle with bloody operating field might be 
an influencing factor to the surgical outcome. The senior author was intrigued by the increased use of epinephrine in other end arterial area such as in the digits by using tumescent technique. This new wave of breaking the dogma of the safety use of epinephrine in hands which was also an end arterial area is the base for this small series. The penile is a blood vesselrich organ so if we do any surgery there without the use of tourniquet, it will bleed excessively and make the operation field relatively unclear.

In this case report, we can see from figure 1 the relatively bloodless operation field with the use of chemical tourniquet. We consider the result of the tumescent was a success. The dissection was also easier because the tumescent acts as a hydro-dissector and created avascular plane. The amount of epinephrine used in this small case series was only 1: 1,000,000. The safety use of epinephrine in end arterial area might be questioned because of many textbooks and references note that digital ischemia can be a problem after the use of epinephrine, especially in concentrated forms. But a study done by Muck, concluded that ischemia after digital epinephrine auto-injection is rare. ${ }^{4}$ So there has been a growing body of evidence that suggests the use of epinephrine in the fingers at the low concentrations $(1: 100,000$ to $1: 200,000)$ for the purpose of digital nerve blocks is safe and without adverse effects. ${ }^{5}$ As in hand surgery it is considered that epinephrine use can be safe depending on the concentration of the epinephrine used then we can relate this to penile surgery. But since we involve skin flap in the reconstruction of hypospadias, we should also take this into consideration. A previous study on skin flap survival on rats injected with epinephrine was already done, and the result was that lidocaine with epinephrine in concentrations of 1:400,000 and 1:800,000 was found safe on skin flap survival for tumescent technique in rats. ${ }^{3}$ In both operation, we did not have any complication of penile ischemia and the flap survived well as we can see in the figure 3 .
In conclusion, tumescent is a well-known technique used by many plastic surgeons but the use of this technique which contains epinephrine in penile surgery has not been reported. In this case report we can see the tumescent solution containing epinephrine acts as a natural hydro-dissector, creating avascular anatomic tissue planes for easier and more rapid dissection. Furthermore, no complication due to epinephrine injection to the penile skin was noted in this study. This result also elaborates the new wave of epinephrine use in finger and hand surgery and breaks the paradigm of the danger of epinephrine injection to the penis.

\section{REFERENCES}

1. Giannantoni A. Hypospadias classification and repair: the riddle of the sphinx. Eur Urol. 2011;60:1190-2.

2. Mustoe TA, Lalonde DH. The safe management of anesthesia, sedation, and pain in plastic surgery. Plast Reconstr Surg. 2010;126(4):165e-76e.

3. Atabey AM, Galdino G, El-shahat A, Ramirez OM. Effects of tumescent solutions containing lidocaine and epinephrine on skin flap survival in rats. Ann Plast Surg. 2004;53(1):70-2.

4. Muck AE, Bebarta VS, Borys DJ, Morgan DL. Six years of epinephrine digital injections: absence of significant local or systemic effects. Ann Emerg Med. 2010;56(3):270-4.

5. Singer AJ. Accidental digital self-injection of epinephrine: debunking the myth. Ann Emerg Med. 2010;56(3):275-7.

6. Ghali S, Knox KR, Verbesey J, Scarpidis U, Izadi K, Ganchi PA. Effects of lidocaine and epinephrine on cutaneous blood flow. J Plast Reconstr Aesth Surg. 2008;61:1226-31.

7. Abbott AM, Miller BT, Tuttle TM. Outcomes after tumescence technique versus electrocautery mastectomy. Ann Surg Oncol. 2012;10:2304-8.

8. Klein J. Tumescent technique for liposuction surgery. Am J Cosmet Surg. 1987;4:263-7.

9. Lapid O. Syringe-delivered tumescent anesthesia made easier. Aesth Plast Surg. 2011;35:601-2. 